\title{
Analysis of Resource Endowments of Mustard Growers in Hamirpur District of Bundelkhand Region Uttar Pradesh
}

\author{
Arvind Kumar ${ }^{1}$, Abhishek Kalia ${ }^{2 *}$, Rahul Kumar Rai ${ }^{3}$, Dheeraj Mishra ${ }^{4}$ and \\ Pankaj Kumar Ojha ${ }^{4}$
}

${ }^{1}$ PG Scholar (Agricultural Economics) ${ }^{2 \& 3}$ Assistant Professor (Agricultural Economics) and ${ }^{4}$ Assistant Professor (Agricultural Extension), Banda University of Agriculture and Technology, Banda, Uttar Pradesh, India

*Corresponding author: abhi0613@gmail.com (ORCID ID: 0000-0003-2234-6742)

Received: $23-06-2021$

Revised: $21-08-2021$
Accepted: 12-09-2021

\begin{abstract}
A vigilant study of the resource endowment conditions of farmers is a precondition for the appropriate design and successful implementation of the government's programs. The study was conducted in Hamirpur district of Bundelkhand during 2019-20 to investigate the resource endowments and socioeconomic status of mustard grower farmers. Maudaha block of Hamirpur was selected, randomly. Primary data was collected from a sample of 120 respondents through structured questionnaire using a multistage sampling. The data indicated that out total respondent's maximum were found illiterate, majority of farmers were having Pakka house. Agriculture was found to be the major source of income for the farmers of Maudaha block and also provided a source of the dietary needs of the family. Average size holding per farm was found highest under large farms followed by medium and small farms. The cropping intensity of Hamirpur was found less than that of whole Bundelkhand region. Buffalo population was found to be increasing in the region over the period.

\section{Highlights}

(0 Occupation distribution shows that maximum was having agriculture as an occupation (i.e. 66.67 per cent) while 33.33 per cent were doing labour work along with agriculture.

( N Number of holdings were found maximum under marginal farms category and average size holding per farm was found highest under large farms.

(- Cropping intensity of the region was found low because of not raising two or more crops in different season due to unexpected rainfall and due to lack of irrigation facilities.

( Per farm availability of Cow and buffalo was found highest in Large farms and of Goat and Sheep was found highest in marginal farms.
\end{abstract}

Keywords: Multistage sampling, marginal, respondents, mustard growers, Bundelkhand

Oilseed have been considered as one of the oldest cultivated plants in human civilization and an indispensable part of the Indian diet from time immemorial and ancient scriptures such as Puranas and Mahabharata have also quoted their reference in it. Being an important part of human diet, in the present world mustard is an important source of income for those who are directly or indirectly involved in its production and marketing. In the year 2018-19 total cultivated area in the world was estimated 36.59 million hectares, with a production of 72.37 million tonnes and all time highest productivity of 19.80 quintals per hectare. A major share of produce of leading Asian countries like India, Nepal, China and Myanmar get utilized as cooking oil. Worldwide acreage share of India

How to cite this article: Kumar, A., Kalia, A., Rai, R.K., Mishra, D. and Ojha, P.K. (2021). Analysis of Resource Endowments of Mustard Growers in Hamirpur District of Bundelkhand Region Uttar Pradesh. Economic Affairs, 66(3): 473-479.

Source of Support: None; Conflict of Interest: None 
in Mustard cultivation is 19.8 per cent and in production its share is 9.8 per cent (USDA, 2020). During the 10 years' whole world witnessed a significant rise in production and productivity of mustard as the production increased from 61.64 million tonnes in 2010-11 to 72.37 million tonnes in 2018-19 whereas the productivity jumped from 18.40 quintals per hectare in 2010-11 to 19.80 quintals per hectare in 2018-19. According to (DRMR, 2020) Canada holds the largest area (8.3 million hectares) in mustard cultivation followed by India (7.4 million hectares) and China (6.6 million hectares). Even after having the second highest area under mustard cultivation, the productivity of mustard is very low in India i.e. 14 quintals per hectare whereas of Chile it is recorded highest with 41 quintals per hectare. In India, Rajasthan stands as the leading producer with highest area and production followed by Madhya Pradesh and Uttar Pradesh respectively. During the last five years, area as well as production of Uttar Pradesh and its Bundelkhand has shown significant rise (Kalia et al. 2020). This study is an effort to analyse the status of resource endowments of Mustard growers of Hamirpur district of Bundelkhand region so that better policies can be framed for them.

\section{Methodology}

The study was purposively confined to Bundelkhand region of Uttar Pradesh. There are 7 districts namely Banda, Mahoba, Chitrakoot, Jalaun, Jhansi, Lalitpur and Hamirpur comes under this region. Bundelkhand region is considered as a disadvantaged region so it was selected purposively along with reason that it comes under the operational area of our university. An appropriate sampling is essential for obtaining required information. For the selection of sample farmers, a multistage sampling procedure was adopted for the selection of districts, blocks, villages and farmers in the study area. As there are seven districts comes under Bundelkhand region. In the first stage, Hamirpur district was selected purposively for study on the basis of having higher production and area under mustard crop. There are seven blocks in Hamirpur namelyKurara, Maudaha, Sumerpur, Sarila, Gohand and Rath, out of which, Maudaha block was selected purposively on the basis of higher production of the mustard crop.

\section{Research Location: Maudaha Block of Hamirpur district}

The early history of the region covered by the present district of Hamirpur may be traced back to the Paleolithic age as evidenced by the discovery of choppers, hand axes and pebble cores. In the eleventh century, the town of Hamirpur was founded by one Hamira Deva, a Kalachuri Rajput. The remains of the fort built by Hamira Deva are still found in Hamirpur. The district is located on the right banks of the Yamuna river. It lies between Latitude $25.95 \mathrm{~N}$ and Longitude 80.15E.Hamirpur covers an area of $4121.9 \mathrm{~km}^{2}$. The district shares its boundary with districts Jalaun, Kanpur and Fatehpur in north, Mahoba in South, district of Jhansi and Jalaun on the west and Banda in east. Hamirpur is divided into 7 development blocks namely; (1) Gohand (2) Kurara (3) Maudaha (4) Muskara (5) Rath (6) Sarila and (7) Sumerpur. From the selected block four villages were selected randomly and from each village 30 respondents/ farmers have been selected randomly to make a sample of 120 farmer households.

\section{Demographic profile of Hamirpur}

Hamirpur district: According to census report 2011 the district Hamirpur has a population of 1104285 . The total population 51.5 per cent are male and 48.5 percent female respectively.

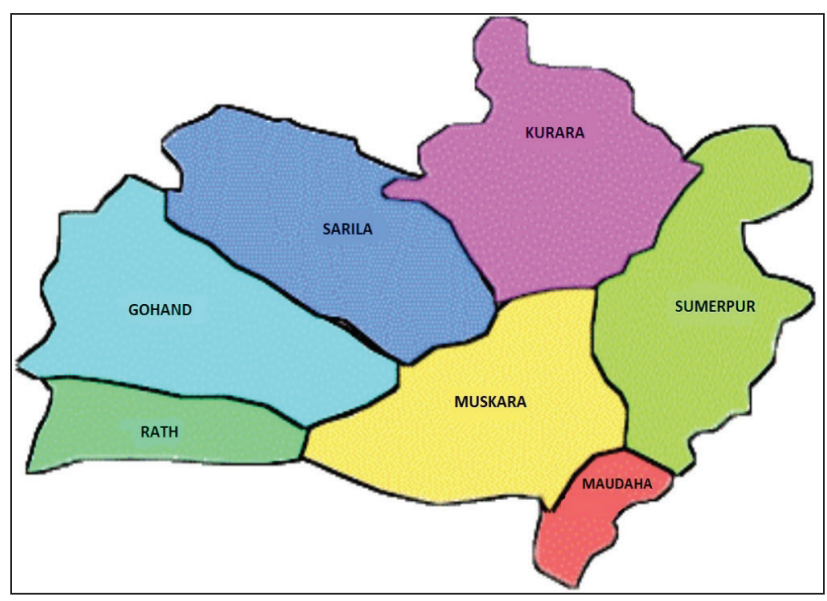

Fig. 1: Map of district Hamirpur, Uttar Pradesh

As a result of consistent growth in population, the pressure on land goes on increasing day by day and in turn reduces the per capita of both the total and the agriculture land. The land availability of Hamirpur district 0.35 hectare and net sown are 
a availability 0.23 hectare maximum area sown in Hamirpur is in Rabi season 58.38 percent followed by Kharif 41.38 percent and Zaid with 0.20 percent respectively and if the facilities of irrigation are further strengthened and insured there is vast scope of increasing area under summer crops in the study area.

\section{RESULTS AND DISCUSSION}

Table 1 describes about the various socio economic status, among all the sample farm categories total number of land holding was found maximum under marginal farms category (50), followed by small farms (36), medium farms (27) and large farms (7) respectively. Among all the 120 sample farms, 29 per cent i.e. 35 were found illiterate, 17.5 per cent i.e. 21 have gone for primary education only, 25.83 per cent i.e. 31 have continued till secondary education, 20 per cent have taken education up to higher secondary level. Only 7.5 percent sample farms were found graduate and none was found Post Graduated. Among all the sample farms, most of them i.e. 68.33 percent were having pakka house, 29 percent were having Kachha house and only 1.66

Table 1: Distribution of Mustard growers as per Socio economic status and agrarian structure in Maudaha block of Hamirpur district

\begin{tabular}{|c|c|c|c|c|}
\hline S1. No. & Dimensions & Category & Frequency & Percentage \\
\hline \multirow[t]{5}{*}{1} & \multirow[t]{5}{*}{ Land Holding } & Marginal (<1 ha) & 50 & 41.7 \\
\hline & & Small (1- 2 ha) & 36 & 30 \\
\hline & & Medium (2-10 ha) & 27 & 22.5 \\
\hline & & Large (>10 ha) & 7 & 5.8 \\
\hline & & Total & 120 & 100 \\
\hline \multirow[t]{7}{*}{2} & \multirow[t]{7}{*}{ Education } & Illiterate & 35 & 29 \\
\hline & & Primary & 21 & 17.5 \\
\hline & & Secondary & 31 & 25.83 \\
\hline & & Higher Secondary & 24 & 20 \\
\hline & & Graduation & 9 & 7.5 \\
\hline & & Post-Graduation & 0 & 0 \\
\hline & & Total & 120 & 100 \\
\hline \multirow[t]{4}{*}{3} & \multirow[t]{4}{*}{ House } & Hut & 2 & 1.66 \\
\hline & & Kachha House & 35 & 29 \\
\hline & & Pakka House & 83 & 68.33 \\
\hline & & Total & 120 & 100 \\
\hline \multirow[t]{7}{*}{4} & \multirow{7}{*}{$\begin{array}{l}\text { Family size (out of } 120 \\
\text { families) }\end{array}$} & Male & 315 & 56.5 \\
\hline & & Female & 243 & 43.5 \\
\hline & & Total & 588 & 100 \\
\hline & & Adult & 130 & 22.1 \\
\hline & & Children & 289 & 51 \\
\hline & & Old & 139 & 24.9 \\
\hline & & Total & 588 & 100 \\
\hline \multirow[t]{4}{*}{5} & \multirow[t]{4}{*}{ Caste } & S.C/S.T & 45 & 37.5 \\
\hline & & O.B.C & 54 & 45 \\
\hline & & Gen. & 21 & 17.5 \\
\hline & & Total & 120 & 100 \\
\hline \multirow[t]{3}{*}{6} & \multirow[t]{3}{*}{ Occupation } & Agriculture & 80 & 66.67 \\
\hline & & $\begin{array}{l}\text { Agriculture + labour } \\
+ \text { others }\end{array}$ & 40 & 33.33 \\
\hline & & Total & 120 & 100 \\
\hline
\end{tabular}


per cent were found living in hut. Among all the 120 sample farms family, 56.5 per cent i.e. 315 male members and 43.5 per cent i.e. 243 female members were there. 22.10 per cent i.e. 130 members were found adults followed by 51 percent (289) children and 24.90 per cent (139) were found senior citizens. The cast was the most distinctive feature of the sample mustard growers, it revealed that highest 45 per cent belongs to the O.B.C category followed by 37.5 per cent SC/ST category and only 17.5 per cent belongs to general or unreserved category. Occupation distribution shows that maximum was having only agriculture as an occupation while 33.33 per cent were doing labour work along with agriculture.

Table 2 shows the distribution of land holding in Maudaha block of Hamirpur district. No. of holding is maximum under marginal farms category i.e. 50 (41.16 per cent) followed by small farms 37 (30 per cent), medium farms 27 (22.5 per cent) and large farms 7 (5.83 per cent). Area under the cultivation is maximum under medium farm category i.e. 102.4 hectares (38.60 per cent) followed by large farms 73 hectares (27.5 per cent), small farms 52.56 hectare (19.8 per cent) and marginal farms 37.28 hectare (14.05 per cent) of the total 265.24 hectare (100 per cent). Average size holding per farm is highest under large farms i.e. 10.73 ha followed by medium farms 3.79 ha, small farms 1.42 ha and marginal farms 0.74 ha. On all farm basis Average size holding per farm is 4.17 ha. The findings are also found in the line of the findings of Kalia et al. (2015) and Singh et al. (2018).
Table 3 reveals that the intensity of cropping in Maudaha block is 112 per cent with the net cultivated area is 95.7 ha and the total cropped area is 106.3 ha. Cropping intensity of U.P. is 158 per cent, in Bundelkhand region it is 140 per cent and in Hamirpur district it counts for 128 per cent (Singh et al. 2018). This is because of most of the land is still not subjected to raising two or more crops in different season due to unexpected rainfall, due to lack of irrigation facilities and damage caused to crop by stray animals (Anna Pratha).

Table 4 shows the availability of livestock under per farm and per hectare category. In case of cow, Maudaha block medium farms have 0.85 cows followed by marginal farms 0.8 , medium farms 0.62 and small farms 0.61 per farm, on overall per farm basis Maudaha block have 2.9 cows. On per hectare basis marginal farms have 1.08 cows followed by small farms 0.41 , medium farms 0.20 and large farms 0.08 cows respectively, overall 1.77 cows were present on per hectare basis in Maudaha block.

Per farm availability of the buffalo is highest in large farms (3.71) followed by Medium farms (1.55), small farms (1.30) and marginal farms (0.90) respectively. On overall per farm basis Maudaha block have 7.5 buffaloes. On per hectare basis marginal farms have Medium farms (1.55), small farms (1.30) and marginal farms (0.90) respectively. On overall per farm basis Maudaha block have 7.5 buffaloes. On per hectare basis marginal farms have highest 1.26 buffaloes followed by small farms 0.89 , medium farms 0.41 and large farms 0.35 cows respectively,

Table 2: Distribution of average size of land holding (ha) in Maudaha block of Hamirpur district

\begin{tabular}{llllll}
\hline Categories & $\begin{array}{l}\text { No. of } \\
\text { holding }\end{array}$ & $\begin{array}{l}\text { Percentage of } \\
\text { total holding }\end{array}$ & $\begin{array}{l}\text { Area under } \\
\text { cultivation (ha.) }\end{array}$ & $\begin{array}{l}\text { Percentage to total area } \\
\text { under cultivation }\end{array}$ & $\begin{array}{l}\text { Average size of } \\
\text { holding per farm (ha) }\end{array}$ \\
\hline Marginal & 50 & 41.16 & 37.28 & 14.05 & 0.74 \\
Small & 37 & 30.0 & 52.56 & 19.8 & 1.42 \\
Medium & 27 & 22.5 & 102.4 & 38.60 & 3.79 \\
Large & 7 & 5.83 & 73 & 27.5 & 10.73 \\
\hline Total & $\mathbf{1 2 0}$ & $\mathbf{1 0 0}$ & $\mathbf{2 6 5 . 2 4}$ & $\mathbf{1 0 0}$ & $\mathbf{4 . 1 7}$ \\
\hline
\end{tabular}

Table 3: Distribution of cropping intensity in Maudaha block of the Hamirpur district

\begin{tabular}{llllll}
\hline Particulars & Marginal & Small & Medium & Large & All Farms \\
\hline Total cropped area (ha) & 58.44 & 72.88 & 179.68 & 114.56 & 106.39 \\
Net cultivated area (ha) & 47.43 & 67.21 & 154.82 & 113.43 & 95.7225 \\
Cropping intensity (\%) & 123 & 109 & 116 & 101 & 112 \\
\hline
\end{tabular}


Analysis of Resource Endowments of Mustard Growers in Hamirpur District of Bundelkhand Region... T A

Table 4: Distribution of Livestock in Maudaha block of the Hamirpur district

\begin{tabular}{|c|c|c|c|c|c|c|c|c|c|c|c|c|c|}
\hline \multirow[b]{2}{*}{$\begin{array}{l}\text { Sl. } \\
\text { No. }\end{array}$} & \multirow[b]{2}{*}{ Category } & \multicolumn{3}{|c|}{ Cow } & \multicolumn{3}{|c|}{ Buffalo } & \multicolumn{3}{|c|}{ Goat } & \multicolumn{3}{|c|}{ Sheep } \\
\hline & & $\begin{array}{l}\text { Per } \\
\text { Farm }\end{array}$ & Per ha & Total & $\begin{array}{l}\text { Per } \\
\text { Farm }\end{array}$ & Per ha & Total & $\begin{array}{l}\text { Per } \\
\text { Farm }\end{array}$ & Per ha & Total & $\begin{array}{l}\text { Per } \\
\text { Farm }\end{array}$ & Per ha & Total \\
\hline 1 & Marginal & 0.82 & 1.08 & 41 & 0.94 & 1.26 & 47 & 1.36 & 1.82 & 68 & 0.16 & 0.21 & 8 \\
\hline 2 & Small & 0.61 & 0.41 & 22 & 1.30 & 0.89 & 47 & 1.25 & 0.85 & 45 & 0.11 & 0.07 & 4 \\
\hline 3 & Medium & 0.62 & 0.20 & 15 & 1.55 & 0.41 & 42 & 0.22 & 0.05 & 6 & 0.11 & 0.02 & 3 \\
\hline 4 & Large & 0.85 & 0.08 & 6 & 3.71 & 0.35 & 26 & 1.00 & 0.09 & 7 & 0.00 & 0.00 & 0 \\
\hline 5 & Total & 2.9 & 1.77 & 84 & 7.5 & 2.91 & 162 & 3.84 & 2.81 & 126 & 0.38 & 0.3 & 15 \\
\hline
\end{tabular}

Table 5: Distribution of Implements and Machinery in Maudaha block of the Hamirpur district

\begin{tabular}{|c|c|c|c|c|c|c|}
\hline Sl. No. & Particulars/Category & Marginal & Small & Medium & Large & All Farms \\
\hline \multirow[t]{4}{*}{1} & Tractor & & & & & \\
\hline & (a) Total No. & 0 & 6 & 8 & 6 & 5 \\
\hline & (b) Per farm & 0 & 0.16 & 0.29 & 0.85 & 0.12 \\
\hline & (c) Per ha & 0 & 0.16 & 0.07 & 0.08 & 0.15 \\
\hline \multirow[t]{4}{*}{2} & Cultivator & & & & & \\
\hline & (a) Total No. & 0 & 5 & 7 & 7 & 4.75 \\
\hline & (b) Per farm & 0 & 0.13 & 0.25 & 1 & 0.34 \\
\hline & (c) Per ha & 0 & 0.13 & 0.06 & 0.095 & 0.07 \\
\hline \multirow[t]{4}{*}{3} & Seed Drill & & & & & \\
\hline & (a) Total No. & 0 & 5 & 7 & 7 & 4.75 \\
\hline & (b) Per farm & 0 & 0.13 & 0.25 & 1 & 0.34 \\
\hline & (c) Per ha & 0 & 0.095 & 0.06 & 0.25 & 0.11 \\
\hline \multirow[t]{4}{*}{4} & Thresher & & & & & \\
\hline & (a) Total No. & 0 & 5 & 6 & 7 & 4.5 \\
\hline & (b) Per farm & 0 & 0.13 & 0.22 & 1 & 0.33 \\
\hline & (c) Per ha & 0 & 0.095 & 0.05 & 0.095 & 0.06 \\
\hline \multirow[t]{4}{*}{5} & Rotavator & & & & & \\
\hline & (a) Total No. & 0 & 0 & 1 & 1 & 0.5 \\
\hline & (b) Per farm & 0 & 0 & 0.03 & 0.14 & 0.042 \\
\hline & (c) Per ha & 0 & 0 & 0.009 & 0.013 & 0.003 \\
\hline \multirow[t]{4}{*}{$\overline{6}$} & Harrow & & & & & \\
\hline & (a) Total No. & 0 & 1 & 1 & 2 & 0.25 \\
\hline & (b) Per farm & 0 & 0.027 & 0.03 & 0.28 & 0.02 \\
\hline & (c) Per ha & 0 & 0.026 & 0.009 & 0.027 & 0.003 \\
\hline \multirow[t]{4}{*}{7} & M.B plough & & & & & \\
\hline & (a) Total No. & 0 & 0 & 1 & 2 & 0.75 \\
\hline & (b) Per farm & 0 & 0 & 0.03 & 0.023 & 0.13 \\
\hline & (c) Per ha & 0 & 0 & 0.009 & 0.027 & 0.036 \\
\hline \multirow[t]{4}{*}{8} & Chaff cutter & & & & & \\
\hline & (a) Total No. & 18 & 21 & 17 & 7 & 15.75 \\
\hline & (b) Per farm & 0.36 & 0.72 & 0.62 & 1 & 0.67 \\
\hline & (c) Per ha & 0.48 & 0.39 & 0.16 & 0.095 & 0.17 \\
\hline \multirow[t]{4}{*}{9} & Others (Spade, etc.). & & & & & \\
\hline & (a) Total No. & 60 & 40 & 30 & 10 & 35 \\
\hline & (b) Per farm & 1.2 & 1.08 & 1.11 & 1.42 & 1.20 \\
\hline & (c) Per ha. & 1.60 & 0.76 & 0.29 & 0.13 & 0.69 \\
\hline
\end{tabular}


overall 2.91 buffaloes were present on per hectare basis in Maudaha block.

Per farm availability of the Goat is highest in marginal farms (1.36) followed by small farms (1.25), large farms (1.0) and medium farms (0.22) respectively. On overall per farm basis Maudaha block have 3.84 goats. On per hectare basis marginal farms have highest 1.82 goats followed by small farms 0.85 , large farms 0.09 and medium farms 0.05 respectively, overall 2.81 goats were present on per hectare basis in Maudaha block.

Per farm availability of the sheep is highest in marginal farms (0.16) followed by small farms (0.11) respectively. On overall per farm basis Maudaha block have 0.38 sheep. On per hectare basis marginal farms have highest 0.21 sheep followed by small farms 0.07 , and medium farms 0.02 sheep respectively, overall 0.3 sheep were present on per hectare basis in Maudaha block.

Table 5 shows the availability of various implements in Maudaha block. It becomes clear that among all the categories of farms, large farms have more numbers of tractors on per farm i.e. 0.85 and small farms (0.16) on per hectare basis. On overall per farm and per hectare basis Maudaha block have 0.12 and 0.15 tractors, respectively.

Per farm availability of the cultivator is highest in large farms (1.00) and per hectare in small farms (0.13). On overall per farm and per hectare basis Maudaha block have 0.34 and 0.07 cultivators, respectively.

Per farm availability of the Seed drill is highest in large farms (1.00) and per hectare availability was highest in small farms (0.25), respectively. On overall per farm and per hectare basis Maudaha block have 0.34 and 0.11 seed drills, respectively.

Likewise, per farm and per hectare availability of thresher is highest in large farms (1.00) and per hectare availability was highest in small farms (0.06). On overall per farm and per hectare basis Maudaha block have 0.33 and 0.06 cultivators, respectively.

In case of rotavator, mould board plough, harrow and chaff cutter, the same trend has been followed. Per farm and per hectare availability of these implements was found highest in large farms followed by small farms. However, in case of other small implements like spade, etc., it was found that per farm availability was highest in large farms
(1.42) and per hectare availability was highest in marginal farms (1.60), respectively. Overall per farm and per hectare availability of other small farm implements were recorded as 1.20 and 0.69 , respectively.

\section{CONCLUSION}

In the conducted study resource endowments analysis of Mustard growers was performed. Majority of the farmers were found illiterate or having secondary school level of education. Agriculture was found to be the major source of income for the farmers of Maudaha block and also provided a source of the dietary needs of the family. Average size holding per farm was found highest under large farms followed by medium and small farms. The cropping intensity of Hamirpur was found less than that of whole Bundelkhand region. In Bundelkhand region livestock population especially cattle seem to be a liability rather than an asset from a macro perspective that looks at long-term effects of environmental degradation. Although, considerable effort is made by state government to improve cross-bred cattle numbers, but it appears that state has not been able to make very negligible dent in Bundelkhand region. Over the years, farmers in the region have begun to prefer buffalo rearing although buffalo population in Bundelkhand region is about 5 percent of Uttar Pradesh buffalo population, but it is interesting to note that buffalo population is increasing in the region over the period. It is interesting to note that semi-intensive buffalo rearing is followed in the region by the farmers (Rathod and Dixit, 2020). The per farm and per hectare availability of implements and machinery were observed to increase with increase in the size of the farms. These above findings are supported by the findings of Singh et al. (2018) and Umasankar et al. (2019).

\section{REFERENCES}

DRMR. 2020. Directorate of Rapeseed-Mustard Research. Retrieved September 12,2020, from www.drmr.res. in:www. drmr.res.in/about_rmcrop.php)

Gautam, D.S. 1999. Profit structure of Bajra, Wheat and Rapeseed/Mustard cultivation in central India. Indian J. Agri. Res., 33(3): 171-177.

Kalia, A., Sen, C., Singh, S.K., Singh, U.P., Tripathi, A.K., and Mishra, S. 2015. Comparative analysis of resource endowments in different regions of Eastern Uttar Pradesh. Ecology Env. and Conserv., 21(Suppl): 259-256. 
Kalia, A., Shukla, G., Mishra, D., Mishra, B.P., and Patel, R.R. 2021. Comparative Trend Analysis of Mustard in Bundelkhand Region, Uttar Pradesh and India. Indian J. Ext. Edu., 57(1): 15-19.

Kumar, R., Gupta, J.K., Gurjar, N.S., Bhadouria, A.K.S. and Rathor, N. 2018. Analysis of resource use efficiency and constraints of mustard production in Bhind District of Madhya Pradesh. J. Pharmacognosy and Phytochemistry, SP2: 219-221.

Kurrey, D.K. and Jain, B.C. 2018. Economics of groundnut crop in Raigarh district of Chhattisgarh state. International J. Pure and Appl. Biosci., 6(2): 1170-1174.

Masudkar, D.D., Kamble, V.B. and Anarase, M.S. 2017. Socio economic status of farmer in adopted village. $J$. Pharmacognosy and Phytochemistry, SPI: 1117-1119.

NMOOP. 2017. Status Paper on Rape-Seed Mustard. MoA\&FW, GoI, New Delhi: National Missionon Oilseeds and Oil Palm.

Rahman, S. 2015. Financial profitability and resource use efficiency of mustard cultivation some selected area of Tangail district. Thesis, M.Sc. SBA University, Dhaka.

Rathod, P. and Dixit, S. 2020. Dairying in Bundelkhand region of Uttar Pradesh: Constraints to realizing the potential. Indian J. Anim. Sci., 90(1): 3-11.
Shukla, K. and Singh, N. 2018. Study of Socio-economic Status of Onion Farmers in Nashik District of Maharashtra. Int. J. Agri. Sci.,10(12): 6425-6427.

Singh, M., Sridhar, K.B., Kumar D., Tewari R.K., Dev, I., Ram, A., Uthappa, A.R, Kumar, V., Singh, R. and Dwivedi, R.P. 2018. Options and Strategies for Farmer's Income Enhancement in Bundelkhand Region of Central India. Technical BulletinNo.2/2018. ICAR-CAFRI, Jhansi, India. 50.

Umasankar, Singh, G.P., Ahmad, R., Sengar, V.S., Kishore, K. and Chaudhary, B. 2019. Study of farm structure, cropping pattern and cropping intensity on Lentil growing sample farms in Lakhimpur (Kheri) district of Uttar Pradesh. Journal of Pharmacognosy and Phytochemistry, 8(3): 40294033.

Yadav, M.K. and Sharma, A. 2019. Assessment of resource use efficiency of rapeseed and mustard to farm size in to block of Jaipur district, Rajsthan. J. Env. Sci. Pharmacology and Life Sci., 8(5): 78 -84. 
